\title{
The effect of selenium source on performance, carcass traits, oxidative status of the organism, and meat quality of turkeys
}

\author{
D. Mikulski ${ }^{1,4}$, J. Jankowski ${ }^{1}$, Z. Zduńczyk², M. Wróblewska², \\ K. Sartowska ${ }^{3}$ and T. Majewska ${ }^{1}$
}

\author{
${ }^{1}$ University of Warmia and Mazury, Department of Poultry Science \\ Oczapowskiego 5, 10-718 Olsztyn, Poland \\ ${ }^{2}$ Institute of Animal Reproduction and Food Research, Polish Academy of Sciences \\ Tuwima 10, 10-747 Olsztyn, Poland \\ ${ }^{3}$ Alltech European Biosciences Centre \\ Dunboyne, Ireland
}

(Received 16 January 2009; revised version 21 April 2009; accepted 24 June 2009)

\begin{abstract}
The aim of the present study was to verify the assumption that supplementation of the diet for turkeys with selenium, especially in an organic source of Se, improves the antioxidative status of the organism and the stability of the meat. Seven hundred and twenty 1-d-old BUT9 female turkeys were randomly assigned into three experimental groups (8 pens with 30 turkeys in each) and fed a diet without Se supplementation (Se-0) or a diet containing $0.3 \mathrm{mg} / \mathrm{kg}$ Se in the form of sodium selenite $(\mathrm{SeS})$ or Se-enriched yeast (SeY). The trial was conducted for 112 days.

The growth performance of turkeys was not affected by the dietary Se source. Dietary supplementation with $0.3 \mathrm{mg} / \mathrm{kg}$ SeS caused no significant changes in blood glutathione peroxidase (GPx) or superoxide dismutase activity. GPx activity was significantly $(\mathrm{P}<0.05)$ higher in birds fed a diet containing $0.3 \mathrm{mg} / \mathrm{kg}$ of organic selenium, compared with groups Se- 0 and SeS, both in week 8 and 16. Dietary supplementation with Se-enriched yeast instead of sodium selenite significantly $(\mathrm{P}<0.05)$ increased the crude fat content of breast muscles and breast muscle selenium concentration $(0.468 \mathrm{vs} 0.224 \mathrm{mg} / \mathrm{kg})$. However, the selenium concentration in meat from group SY turkey hens was twofold higher than in group SeS, and threefold higher than in the control treatment. Dietary supplementation with $0.3 \mathrm{mg} / \mathrm{kg}$ of inorganic or organic selenium resulted in a significant $(\mathrm{P}<0.05)$ decrease in thiobarbituric acid reactive substance in raw and stored meat. A tendency towards lower drip loss (11.1-12.7\%) and cooking loss (5.5\%) was observed in meat from turkeys fed a diet with the addition of Se-enriched yeast, compared with turkeys given sodium selenite. In conclusion, both
\end{abstract}

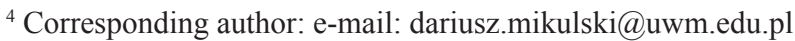


Se sources had the same positive effect on the oxidative stability of turkey meat during refrigerated storage, however, the Se-yeast were more effective in Se-enrichment of breast muscles.

KEY WORDS: Se-enriched yeast, sodium selenite, plasma glutathione peroxidase, performance, meat quality, turkey

\section{INTRODUCTION}

Selenium (Se) is an essential trace mineral and is known to have important roles in a number of biochemical functions in humans and animals, such as antioxidant defense, immune function, reproduction, and thyroid hormone metabolism (Surai, 2002). Selenium also regulates a major component of the antioxidant defense mechanism in all living tissues by controlling the body's glutathione (GSH) pool and its major Se-containing antioxidant enzymes, glutathione peroxidase (GPx) and thioredoxin reductase (Tapiero et al., 2003). Glutathione and GPx have the capacity to protect the integrity of unsaturated bonds of membrane phospholipids by extinguishing free radical attacks capable of initiating and propagating lipid oxidation (Korniluk et al., 2004; Rayman, 2004).

Se deficiency in young turkeys, especially when accompanied by vitamin E deficiency, causes Se-deficiency diseases and dysfunctions, including exudative diathesis, pancreatic dystrophy, and nutritional muscle dystrophy of the gizzard, heart and skeletal muscle (Cantor et al., 1982). Therefore, the NRC recommendation (1994), derived at a lower performance level and amounting only to $0.20 \mathrm{mg} \mathrm{Se} /$ $\mathrm{kg}$ diet, should be re-evaluated. Recent analyses of selenium concentrations in different organs and in plasma as well as of glutathione peroxidase activity in the liver and in plasma indicate that a selenium requirement of $0.30 \mathrm{mg} \mathrm{Se} / \mathrm{kg}$ diet is necessary in fast-growing turkeys (Fischer et al., 2008).

Selenium in animal diets is supplemented primarily as inorganic sodium selenite (SeS) or sodium selenate. Recently however, there has been interest in the use of organic forms, such as selenomethionine (SeM) or Se-enriched yeast (SeY), as supplemental sources of Se (Rayman, 2004). Organic selenium from Se-enriched yeast is equivalent or even superior to sodium selenite in terms of gut absorption and accumulation in the tissue of broilers (Collins et al., 1993). Studies of diets supplemented with either sodium selenite or Se-enriched yeast have shown that organic selenium is deposited more effectively in broiler breast muscles than inorganic selenium (Payne and Southern, 2005). Similar results were obtained earlier in experiments on pigs (Mahan, 1996; Mahan and Parret, 1996) and more recently in experiments on turkeys (Fischer et al., 2008) and sheep (Niedźwiedzka et al., 2008). Increased tissue concentrations of selenium not only 
decrease oxidative stress, including protection of unsaturated fatty acids from peroxidation damage (Tapiero et al., 2003; Korniluk et al., 2007), but can also reduce drip loss from breast meat and the incidence of pale soft, exudative meat (Downs et al., 2000; Naylor et al., 2000). This indicates that dietary selenium can improve the quality and oxidative stability of meat. With this in mind, the aim of the present study was to verify the following hypothesis: dietary supplementation with selenium for turkeys, especially in organic form, improves the antioxidative status of the organism and the oxidative stability of meat.

\section{MATERIAL AND METHODS}

\section{Birds, management and feeding}

The experiment was carried out on an experimental poultry farm of the Department of Poultry Science at the University of Warmia and Mazury in Olsztyn (Poland). Turkey rearing conditions and handling procedures were approved by the local Ethics Committee for experiments on animals at the University of Warmia and Mazury in Olsztyn (Poland).

Birds were kept in $10 \mathrm{~m}^{2}$ pens on litter in a building with a controlled environment, equipped with central heating. Rings for poults (up to 10 days of age) and additional sources of heat (up to 28 days of age) were fitted inside pens. Temperature and humidity levels were monitored daily at 8 a.m. and 3 p.m. The following light program was adapted: $24 \mathrm{~h}$ lighting with an intensity of $100 \mathrm{~lx}$ in the first $72 \mathrm{~h}$, followed by $18 \mathrm{~h}$ of light per day until day 14, and $16 \mathrm{~h}$ of light per day until the end of the growing period. Light intensity was reduced to $5 \mathrm{~lx}$ between day 3 to 7 , and it was gradually increased to $15 \mathrm{~lx}$ as of week 5 . Air exchange was maintained at $0.4-0.5 \mathrm{~m}^{3} / \mathrm{h} / \mathrm{kg}$ body weight (BW) until week 7 and at $7-8 \mathrm{~m}^{3} / \mathrm{h} / \mathrm{kg}$ BW from week 8 until the end of the growing period.

The trial was conducted for 112 days. On day 1, poults were administered Nobilis TRT vaccine. During the experiment, birds had free access to feed and fresh water. Every pen was equipped with an automatic feeder which was computer filled from a silo. Turkeys were fed a pelleted diet without growth promoters or coccidiostatics. A four-phase feeding program similar to industry recommendations was applied, and wheat-soyabean meal based diets were fed in each phase. In each growth phase, the basal diet was supplemented with 0 $(\mathrm{Se}-0)$ or $0.3 \mathrm{mg} / \mathrm{kg}$ of Se from sodium selenite $(\mathrm{SeS})$ or $0.3 \mathrm{mg} / \mathrm{kg}$ of Se from Seenriched yeast (SeY; Sel-Plex ${ }^{\circledR}$ - organic selenium produced by Saccharomyces cerevisiae CNCM I-3060 Alltech, Nicholasville, KY). The composition and nutritional value of basal diets are given in Table 1 . The nutritional value of 
basal feed mixtures was calculated based on the feeds composition.

The trials involved 720 1-d-old BUT 9 female turkeys purchased from a hatchery. The birds were randomly assigned to three feeding groups of 240 female turkeys each ( 8 replications of 30 birds each). Control group turkeys were fed basal diets (without supplementation). In the remaining groups, the birds were fed diets supplemented with $0.3 \mathrm{mg} / \mathrm{kg}$ of Se from sodium selenite (group $\mathrm{SeS}$ ) or $0.3 \mathrm{mg} / \mathrm{kg}$ of $\mathrm{Se}$ from $\mathrm{Se}$-enriched yeast (group $\mathrm{SeY}$ ). The

Table 1. Composition and nutritional value of basal diets, $\%$

\begin{tabular}{|c|c|c|c|c|}
\hline \multirow{2}{*}{ Item } & \multicolumn{4}{|c|}{ Weeks } \\
\hline & $1-4$ & $5-8$ & $9-12$ & $13-16$ \\
\hline \multicolumn{5}{|l|}{ Ingredients } \\
\hline wheat & 39.72 & 37.13 & 40.26 & 54.60 \\
\hline maize & 10.0 & 10.00 & 10.00 & 10.00 \\
\hline soyabean meal $(46 \% \mathrm{CP})$ & 39.00 & 43.00 & 37.50 & 24.60 \\
\hline potato protein & 4.10 & - & - & - \\
\hline soyabean oil $(98 \%)$ & 1.30 & 4.80 & 4.80 & 3.60 \\
\hline fat animal $(99 \%)$ & - & - & 3.00 & 3.00 \\
\hline $\mathrm{NaHCO}_{3}$ & 0.10 & 0.10 & 0.15 & 0.20 \\
\hline salt & 0.25 & 0.28 & 0.20 & 0.20 \\
\hline limestone & 1.70 & 1.20 & 1.03 & 0.95 \\
\hline monocalcium phosphate & 1.90 & 1.40 & 1.27 & 1.05 \\
\hline DL methionine 99 & 0.24 & 0.34 & 0.34 & 0.31 \\
\hline L-lysine $\mathrm{HCl}$ & 0.34 & 0.36 & 0.32 & 0.38 \\
\hline L-threonine & 0.05 & 0.09 & 0.13 & 0.11 \\
\hline acidifier & 0.30 & 0.30 & - & - \\
\hline vitamin-mineral premix ${ }^{1}$ & 1.00 & 1.00 & 1.00 & 1.00 \\
\hline \multicolumn{5}{|c|}{ Calculated chemical composition } \\
\hline $\mathrm{ME}, \mathrm{kcal} / \mathrm{kg}$ & 2735 & 2904 & 3134 & 3153 \\
\hline crude protein & 27.48 & 26.00 & 23.89 & 19.70 \\
\hline lysine & 1.70 & 1.60 & 1.43 & 1.17 \\
\hline methionine & 0.63 & 0.68 & 0.66 & 0.58 \\
\hline methionine + cystine & 1.09 & 1.12 & 1.07 & 0.93 \\
\hline threonine & 1.05 & 1.03 & 0.98 & 0.77 \\
\hline tryptophan & 0.32 & 0.30 & 0.28 & 0.22 \\
\hline $\mathrm{Ca}$ & 1.26 & 0.85 & 0.75 & 0.80 \\
\hline available $\mathrm{P}$ & 0.63 & 0.52 & 0.45 & 0.40 \\
\hline $\mathrm{Na}$ & 0.15 & 0.16 & 0.14 & 0.15 \\
\hline
\end{tabular}

${ }^{1}$ supplied the following per kg of feed: IU: vit. A 15000 , vit. $\mathrm{D}_{3} 4$ 500; mg: vit. E 50, vit. $\mathrm{K}_{3} 2.5$, vit. $\mathrm{B}_{1} 3.5$, vit $\mathrm{B}_{2} 10$, vit $\mathrm{B}_{6} 6$, vit $\mathrm{B}_{12} 0.03$, folic acid 2, biotin 0.36 , nicotinic acid 75 , pantothenic acid 21 , choline 600, Mn 150, Zn 90, Fe 60, J 1.0, Co 0.2; g: Ca 1.72; the background levels of Se in basal diets averaged $0.16 \mathrm{mg} / \mathrm{kg}$ during the course of the study (Se-0 treatment). Vitamin-mineral premix in experimental diets containing; $0.3 \mathrm{mg} / \mathrm{kg}$ of Se from $\mathrm{Na}_{2} \mathrm{SeO}_{3}(\mathrm{SeS})$ or $0.3 \mathrm{mg} / \mathrm{kg}$ of Se from Seenriched yeast (SeY; Sel-Plex ${ }^{\circledR}$, Alltech, Nicholasville, KY) 
background levels of Se in basal diets were calculated; they averaged $0.16 \mathrm{mg} / \mathrm{kg}$ during the course of the study.

During the trials, feed consumption, mortality and culling rates, including the causes thereof, were registered in each pen. Each turkey was weighed on day 28, 56,84 and 112 of the experiment.

\section{Sample collection and analysis}

On day 56 and 112, blood samples were taken from the wing vein of 8 turkeys per treatment to determine alanine aminotransferase (ALT), aspartate aminotransferase (AST), glutathione peroxidase (GPx), superoxide dismutase activity (SOD), antioxidant capacity of water-soluble compounds (ACW), and antioxidant capacity of lipid-soluble compounds (ACL). Serum AST and ALT were measured with a commercially available test kit (Alpha Diagnostics, Poland). GPx activity (EC 1.11.1.9) was measured using an appropriate whole blood method. This method was based on that of Paglia and Valentine (1967). Glutathione peroxidase catalyses the oxidation of glutathione by cumene hydroperoxide. In the presence of glutathione reductase and NADPH, the oxidized glutathione is immediately converted to the reduced form with concomitant oxidation of NADPH to NADP. The decrease in absorbance at $340 \mathrm{~nm}$ is measured. Superoxide dismutase (EC 1.15.1.1; SOD) activity in erythrocyte lysates was assayed using kits from Randox Laboratories Ltd. (Crumlin, UK) according to the method described by Woolliams et al. (1983). The Randox method uses xanthine and xanthine oxidase to generate superoxide radicals that react with 2-(4-iodophenyl)-3-(4-nitrophenol)-5-phenyltetrazolium (I.N.T.) to form a red formazan dye. SOD activity is then calculated from the degree of inhibition of this reaction compared with a standard curve of SOD. For the determination of the antioxidant capacity of the water-soluble substances (ACW) and lipid-soluble substances (ACL) in the serum of turkeys the photochemiluminescence method was used. The method described by Popov and Lewin (1999) and Photochem ${ }^{\circledR}$ (Analytik Jena AG, Jena, Germany) was used with standard ACW and ACL kits (Analytik Jena AG). The photochemiluminescence method consists of excitation of a photo-sensitizer which results in the generation of the superoxide radical $\mathrm{O}_{2}^{-}$. Quantification is performed using standard compounds such as ascorbic acid (ACW) or Trolox (ACL).

On the last day of the experiment (112 days of age), 40 turkeys with average $\mathrm{BW}$ were selected from each group and sacrificed in a poultry slaughterhouse. Chilled carcasses $\left(4^{\circ} \mathrm{C}, 12 \mathrm{~h}\right)$ were subjected to simplified dissection to determine the yield of breast muscles, thigh muscles, drumstick muscles and abdominal fat content. The $\mathrm{pH}$ of breast muscles was measured $15 \mathrm{~min}, 1 \mathrm{~h}$ and $24 \mathrm{~h}$ post-mortem (Testo $\mathrm{GmbH}$ 206-pH2 meter). All breast 
muscle (Pectoralis major) samples, 5 from each replicate ( 40 per treatment), were used for drip loss analysis. The muscles were weighed, placed in plastic bags and refrigerated $\left(4^{\circ} \mathrm{C}\right)$. The muscles were weighed after 24 and $48 \mathrm{~h}$ of cold storage. Drip loss was calculated as (drip loss / initial muscle weight $) \times 100$.

A total of 40 breast muscle samples from each treatment were analysed to determine cooking loss, chemical composition and selenium concentrations. A further 10 samples of breast muscle per treatment were analysed to determine TBARS levels. To determine cooking loss, fresh breast muscles were weighed $\left(\mathrm{wt}_{\mathrm{m}}\right)$, cooked in a microwave oven $(12 \mathrm{~min}, 480 \mathrm{~W})$ and weighed again $\left(\mathrm{wt}_{\mathrm{c}}\right)$. Cooking loss was calculated as $\left(\mathrm{wt}_{\mathrm{m}}-\mathrm{wt}_{\mathrm{c}}\right) / \mathrm{wt}_{\mathrm{m}} \times 100$. A total of 10 breast muscle samples were comminuted and stored in plastic bags at a temperature of $-20^{\circ} \mathrm{C}$ prior to chemical analyses. The chemical composition of breast muscle was determined by standard methods (AOAC, 1990). Selenium concentrations in meat samples were determined with the use of an UltraMass 700 inductively coupled plasma mass spectrometer with full PC control (Varian, Australia). Meat samples were spectrally mineralized with pure nitric acid with the addition of hydrogen peroxide (Merck) at $100 \mathrm{~atm}$ pressure in a Milestone microwave oven (Italy). Selenium concentrations were determined based on calibration curves developed with the use of high-purity standards (ICP; Merck).

Changes in the oxidative stability of meat lipids were determined in fresh samples (24 h after slaughter) and in samples that were stored at a temperature of $-20^{\circ} \mathrm{C}$ for 70 days, thawed and stored for a further 3 days at $4^{\circ} \mathrm{C}$. Those changes were determined by the method proposed by Draper and Hadley (1990) based on thiobarbituric acid reactive substances (TBARS) levels. Sample absorbance was measured with a Specord 40 spectrophotometer (Analityk Jena AG), and TBARS levels were expressed in terms of nmol malondialdehyde in $1 \mathrm{~g}$ of meat.

\section{Statistical analysis}

The obtained results were validated statistically by one-factorial analysis of variance (ANOVA) and Duncan's multiple range test with the use of Statistica 6.0 PL software. The effect of experimental factors was regarded as significant at $\mathrm{P} \leq 0.05$.

\section{RESULTS}

The body weight of female turkeys in the control group and in treatments fed diets supplemented with inorganic and organic selenium did not differ 
significantly (Table 2). The feed intake of turkeys fed diets containing $0.3 \mathrm{mg} / \mathrm{kg}$ $\mathrm{SeY}$ was lower in all investigated growing periods (by $3.0 \%$ until week 4 and by $1.7 \%$ until week 16) than in groups $\mathrm{SeS}$ and $\mathrm{Se}-0$, but the observed differences were not statistically significant.

Mortality noted up to day 28 in the experimental groups ranged from 0.8 to $2.1 \%$, and was similar in both treatments throughout the entire 16-week period, reaching only $2.1-3.8 \%$ (Table 2 ). The main causes of mortality up to day 28 were gastroenterititis, renal failure, and yolk sac inflammation, followed by cardiovascular failure and cachexia in subsequent weeks of growth.

Table 2. The body weight (BW), feed conversion ratio (FCR) and mortality rate of turkeys fed diets with sodium selenite or Se from Se-enriched yeast ${ }^{1}$

\begin{tabular}{lcccc}
\hline Item & \multicolumn{3}{c}{ Se source $^{2}$} & \multirow{2}{*}{ SEM } \\
\cline { 2 - 4 }$B W, \mathrm{~kg} /$ bird & Se-0 & SeS & SeY & \\
$28 \mathrm{~d}$ & & & & 0.003 \\
$56 \mathrm{~d}$ & 0.816 & 0.798 & 0.812 & 0.012 \\
$84 \mathrm{~d}$ & 3.372 & 3.383 & 3.429 & 0.019 \\
$112 \mathrm{~d}$ & 6.701 & 6.714 & 6.764 & 0.023 \\
$F C R, \mathrm{~kg} / \mathrm{kg} \mathrm{BW}$ & 8.718 & 8.729 & 8.766 & \\
$1-28 \mathrm{~d}$ & & & & 0.016 \\
$1-56 \mathrm{~d}$ & 1.808 & 1.868 & 1.812 & 0.016 \\
$1-84 \mathrm{~d}$ & 2.218 & 2.214 & 2.178 & 0.025 \\
$1-112 \mathrm{~d}$ & 2.322 & 2.331 & 2.305 & \\
Mortality rate, \% & 2.781 & 2.808 & 2.761 & \\
$1-28 \mathrm{~d}$ & & & & \\
1 - 112 d & 2.1 & 1.3 & 0.8 & \\
\hline
\end{tabular}

${ }^{1}$ data represent mean values of eight replicates pens of 30 turkeys each; ${ }^{2}$ experimental diets: $\mathrm{Se}-0$ - wheat based feed without selenium supplements and experimental diets containing $0.3 \mathrm{mg} / \mathrm{kg}$ of Se from $\mathrm{Na}_{2} \mathrm{SeO}_{3}(\mathrm{SeS})$ or $0.3 \mathrm{mg} / \mathrm{kg}$ of Se from Se-enriched yeast $(\mathrm{SeY})$

Feed supplementation with inorganic and organic selenium did not affect ALT and AST activity or the antioxidant capacity of turkey blood serum (Table 3). In week 8 and 16, the levels of the above blood biochemical indicators were similar in all groups. GPx activity increased in turkeys with age (week 16 vs week 8), while SOD activity decreased over that time. The addition of $0.3 \mathrm{mg} /$ $\mathrm{kg}$ inorganic selenium (sodium selenite) to diets for turkeys had no effect on the activity of GPx and SOD. GPx activity was significantly $(\mathrm{P}<0.05)$ higher in turkeys fed the diet with SeY than in group SeS and Se-0, both in week 8 and 16. Similarly to GPx activity, SOD activity was significantly $(\mathrm{P}<0.05)$ higher in group $\mathrm{SY}$ than in group SeS and in the control group in week 8 . Statistically significant differences in SOD activity levels were not found in week 16. 
Table 3. Effect of selenium source and age of turkeys on blood ALT, AST, PGX, SOD, ACW and $\mathrm{ACL}^{1}$

\begin{tabular}{lrcccc}
\hline \multirow{2}{*}{ Item } & \multirow{2}{*}{ Age } & \multicolumn{3}{c}{ Se source $^{2}$} & \multirow{2}{*}{ SEM } \\
\cline { 3 - 5 } & & Se-0 & SeS & SeY & \\
\hline \multirow{2}{*}{ ALT, U/1 } & 8 & 26.90 & 26.70 & 25.00 & 0.969 \\
AST, U/1 & 16 & 39.00 & 38.55 & 36.80 & 1.048 \\
& 8 & 279.0 & 301.8 & 287.2 & 6.002 \\
GPx, U/ml & 16 & 489.0 & 444.0 & 481.9 & 23.54 \\
& 8 & $4.84^{\mathrm{b}}$ & $5.17^{\mathrm{b}}$ & $7.31^{\mathrm{a}}$ & 0.270 \\
$\mathrm{SOD}, \mathrm{U} / \mathrm{ml}$ & 16 & $6.54^{\mathrm{b}}$ & $6.98^{\mathrm{b}}$ & $9.87^{\mathrm{a}}$ & 0.281 \\
& 8 & $84.78^{\mathrm{b}}$ & $87.95^{\mathrm{b}}$ & $101.4^{\mathrm{a}}$ & 1.498 \\
ACW, $\mu \mathrm{mol}$ ascorbic acid/ml & 16 & 63.33 & 73.44 & 75.03 & 3.795 \\
& 8 & 0.187 & 0.183 & 0.186 & 0.004 \\
ACL, $\mu \mathrm{mol}$ Trolox/ml & 16 & 0.465 & 0.448 & 0.391 & 0.008 \\
& 8 & 0.164 & 0.151 & 0.151 & 0.011 \\
& 16 & 0.919 & 0.855 & 0.909 & 0.008 \\
\hline
\end{tabular}

${ }^{1}$ data represent mean values of eight replicates; ${ }^{2}$ as in Table 2; ALT - aminotransferase alanine; AST - aminotransferase aspartate; GPx - glutathione peroxidase; SOD - superoxide dismutase; ACW - antioxidant capacity of water soluble compounds; ACL - antioxidant capacity of lipid soluble compounds

means within the same line with no common superscripts differ significantly: ${ }^{a, b}$ - $\mathrm{P} \leq 0.05$ as a result of a Duncan means comparison

Dietary supplementation with $0.3 \mathrm{mg} / \mathrm{kg} \mathrm{SeS}$ or $\mathrm{SeY}$ did not have a significant effect on carcass yield or the properties of turkey muscles (Table 4).

Table 4. Carcass traits, chemical composition and physicochemical properties of the breast muscles of turkeys fed diets with or without selenium supplements ${ }^{1}$

\begin{tabular}{lrrrr}
\hline \multirow{2}{*}{ Item } & \multicolumn{3}{c}{ Se source } & \multirow{2}{*}{ SEM } \\
\cline { 2 - 4 } \% of body weight & Se-0 & SeS & SeY & \\
dressing percentage & 76.87 & 77.02 & 76.93 & 0.095 \\
abdominal fat & 0.61 & 0.47 & 0.42 & 0.029 \\
thigh muscles & 10.36 & 10.45 & 10.56 & 0.065 \\
rumstick muscles & 7.64 & 7.66 & 7.74 & 0.049 \\
Breast muscles & & & & \\
relative weight, \% BW & 23.12 & 23.56 & 23.60 & 0.106 \\
dry matter, \% & $26.19^{\mathrm{ab}}$ & $26.34^{\mathrm{a}}$ & $25.93^{\mathrm{b}}$ & 0.053 \\
crude protein, \% & $25.18^{\mathrm{b}}$ & $25.63^{\mathrm{a}}$ & $25.17^{\mathrm{b}}$ & 0.058 \\
crude fat, \% & $0.64^{\mathrm{ab}}$ & $0.54^{\mathrm{b}}$ & $0.71^{\mathrm{a}}$ & 0.028 \\
crude ash, \% & 1.17 & 1.18 & 1.16 & 0.010 \\
pH 15 min post-mortem & 6.13 & 6.17 & 6.13 & 0.020 \\
pH 1 h post-mortem & 5.65 & 5.66 & 5.66 & 0.013 \\
pH 24 h post-mortem & 5.55 & 5.58 & 5.57 & 0.010 \\
drip loss of raw meat after 24 h, \% & 0.95 & 0.94 & 0.82 & 0.051 \\
drip loss of raw meat after 48 h, \% & 1.64 & 1.60 & 1.42 & 0.061 \\
cooking loss, \% & 14.38 & 14.43 & 13.63 & 0.319 \\
\hline
\end{tabular}

${ }^{1}$ data represent mean values of 40 replicates; ${ }^{2}$ as in Table 2

means within the same line with no common superscripts differ: ${ }^{\mathrm{a}-\mathrm{b}}$ - $\mathrm{P} \leq 0.05$ 
The abdominal fat content of carcasses of group SeY turkeys was $10.6 \%$ lower than that determined in group Se-0, but the differences were statistically nonsignificant. Feed supplementation with inorganic and organic Se did not result in significant changes in the $\mathrm{pH}$ of turkey meat. The intramuscular fat levels in the breast muscles of SeS turkeys was significantly $(\mathrm{P}<0.05)$ lower, but dry matter and crude protein content was significantly $(\mathrm{P}<0.05)$ higher than in SeY treatment (Table 4). In comparison with Se-0 and SeS, a decrease (by $12.7 \%$ after $24 \mathrm{~h}$ and by $11.1 \%$ after $48 \mathrm{~h}$ ) in drip loss from raw meat and a decrease (by 5.5\%) in drip loss from cooked meat of turkeys receiving SeY was observed. The differences noted in drip loss values were statistically non-significant.

Dietary supplementation with $0.3 \mathrm{mg} / \mathrm{kg}$ inorganic and organic Se resulted in a significant $(\mathrm{P}<0.05)$ increase in selenium concentrations in meat and a significant $(\mathrm{P}<0.05)$ decrease in TBARS levels (Table 5). The selenium content of meat from group $\mathrm{SeY}$ turkeys was twofold higher $(\mathrm{P}<0.05)$ than in group $\mathrm{SeS}$ and nearly threefold higher $(\mathrm{P}<0.05)$ than in group Se-O.

Table 5. Content of selenium and thiobarbituric acid reactive substances (TBARS) in the breast muscles of turkeys fed diets with or without selenium supplements ${ }^{1}$

\begin{tabular}{|c|c|c|c|c|}
\hline \multirow{2}{*}{ Item } & \multicolumn{3}{|c|}{ Se source ${ }^{2}$} & \multirow{2}{*}{ SEM } \\
\hline & Se-0 & $\mathrm{SeS}$ & $\mathrm{SeY}$ & \\
\hline Selenium, $\mathrm{mg} / \mathrm{kg}$ & $0.160^{\mathrm{c}}$ & $0.224^{b}$ & $0.468^{\mathrm{a}}$ & 0.017 \\
\hline \multicolumn{5}{|l|}{ TBARS, nmol/g } \\
\hline after $24 \mathrm{~h}$ & $102.59^{\mathrm{a}}$ & $86.13^{\mathrm{b}}$ & $86.85^{\mathrm{b}}$ & 2.351 \\
\hline after 70 days & $107.50^{\mathrm{a}}$ & $92.36^{\mathrm{b}}$ & $88.89^{\mathrm{b}}$ & 3.124 \\
\hline
\end{tabular}

\section{DISCUSSION}

In the present experiment neither the dietary source nor the level of selenium caused significant changes in the growth parameters of turkeys. Our overall growth performance results are in general agreement with the results of Payne and Southern (2005) who reported that the BWG, FCR, and mortality of broilers were not affected $(\mathrm{P}>0.05)$ by Se source (from $\mathrm{SeS}$ or $\mathrm{SeY})$ or level of supplementation $(0$ or $0.30 \mathrm{mg} / \mathrm{kg} \mathrm{Se})$. By contrast, Naylor et al. (2000) and Wang and Xu (2008) found a significant $(\mathrm{P}<0.05)$ improvement in FCR in broilers fed with organic Se at $0.20-0.25 \mathrm{mg} / \mathrm{kg}$ resulting from lower feed intake while maintaining the same liveweight gain.

This experiment has shown that blood GPx and SOD activity in young turkeys 
is dependent on the form of selenium supplied. The addition of $0.3 \mathrm{mg} / \mathrm{kg} \mathrm{SeS}$ to the diet caused no significant changes in blood GPx or SOD activity in turkeys. In birds fed a diet with $0.3 \mathrm{mg} / \mathrm{kg}$ of organic selenium, the activity of GPx (in week 8 and 16) and SOD (in week 8) was significantly $(\mathrm{P}<0.05)$ higher than in groups Se- 0 and SeS. This also suggests that the bioavailability of organic forms of selenium (Se-enriched yeast) was higher, compared with inorganic forms (sodium selenite).

Selenium, as a component of GSH-Px, acts as a second line of defense against cellular peroxide damage due to the inability of vitamin $\mathrm{E}$ to destroy all metabolic peroxides. For the most part, vitamin $\mathrm{E}$ and selenium are mutually replaceable (except at low levels) and each acts as a sparing mechanism for the other (Combs, 1981). The differences in GPx activity due to Se source, noted in this study, only partly agree with the findings of Wang and $\mathrm{Xu}$ (2008), who reported that Se supplementation increased plasma GPx activity. However, the cited authors observed less pronounced increases in GPx activity following the supplementation of SeS compared with SY. In contrast, Payne and Southern (2005) reported that GPx activity was not affected by Se source or concentration.

In our study, dietary supplementation with $0.3 \mathrm{mg} / \mathrm{kg}$ Se caused no changes in carcass or muscle yield. The differences noted in dry matter, crude protein, and crude fat content of the breast muscles are difficult to interpret. Higher concentrations of crude fat could have a positive effect on the sensory properties of meat. Payne and Southern (2005) also found that carcass traits were not affected ( $\mathrm{P}>0.05)$ by Se source or level of supplementation. According to Downs et al. (2000), carcass and deboned meat yield was not influenced by the addition of $0.3 \mathrm{mg} / \mathrm{kg}$ Se in the form of selenite and Se-enriched yeast. Naylor et al. (2000) reported increased SeY-related yields of legs and thighs with no loss of breast meat yield in studies supplying up to $0.25 \mathrm{mg} / \mathrm{kg}$ as $\mathrm{SeY}$.

In the present study, dietary supplementation with $0.3 \mathrm{mg} / \mathrm{kg} \mathrm{SeS}$ or SeY resulted in a significant $(\mathrm{P}<0.05)$ increase in selenium concentrations in turkey meat, and improved the oxidative stability of lipids. The most striking response to selenium form was noted in the selenium content of breast muscles. Se concentrations in this tissue were significantly $(\mathrm{P}<0.05)$ higher in birds given $0.3 \mathrm{mg} / \mathrm{kg}$ Se from the organic source compared with birds given the same amount of Se from sodium selenite. There was also a tendency towards a decrease in drip loss of raw meat from turkeys fed a diet containing SeY. Contradictory results on the influence of dietary $\mathrm{SeS}$ on Se concentration in poultry meat have been reported. The present results are in agreement with the findings of Wang and $\mathrm{Xu}$ (2008) who observed an increase in breast Se concentrations due to the feeding of SeS. Cantor et al. (1982) or Payne and Southern (2005) demonstrated an increase in breast Se concentrations in poults or chickens fed selenomethionine or Se-enriched 
yeast, however addition of SeS to diets not increase the Se content of the tissue. The present study also proves that turkeys receiving inorganic Se retained less Se in tissues than those receiving SeY. Mahan and Parrett (1996) found that $\mathrm{SeS}$ was retained at a lower concentration in muscle tissue, was less efficiently absorbed, and was excreted in larger amounts than organic Se. Publications in recent years have shown that selenium from organic sources effectively increases the concentration of this microelement, and the concentration of long-chain fatty acids in the tissues (Korniluk et al., 2007; Niedźwiedzka et al., 2008).

Selenium, as a first-level antioxidant, effectively decreases oxidative processes in tissues, thus prohibiting the occurrence of off-flavours. The measurement of TBARS levels in tissues is a widely accepted tool for the assessment of reactive oxygen species production (Gutteridge, 1984). The influence of dietary supplementation with Se on lipid oxidation (measured by the thiobarbituric acid (TBA) reaction method) in the raw thigh muscle of chickens was determined by Ryu et al. (2005). The TBA value suggested that dietary supplementation of Se showed improvements in the oxidative stability of chicken meat after 10 and 12 days of refrigerated storage. Yaroshenko et al. (2004) determined a significantly lower content of malondialdehyde in breast and thigh meat enriched with Se at 0.4 to $0.8 \mathrm{mg} / \mathrm{kg}$ of diet. Dlouha et al. (2008) compared the influence of $0.3 \mathrm{mg} / \mathrm{kg}$ dietary sodium selenite and Se-enriched Chlorella $(\mathrm{SeCH})$ and found that lipid oxidation, as measured by MDA formation, was decreased $(\mathrm{P}<0.05)$ in meat samples after 0,3 and 5 days of cooler storage by $\mathrm{SeCH}$ supplementation.

Beyond the role of selenium in the protection of cells from damage, the dietary selenium source seems to affect meat quality, with particular reference to excessive muscle tissue water loss. Drip loss is a substantial economic problem for companies marketing pieces of chickens and turkeys, and processed products. Northcutt et al. (1994) estimated that drip loss can account for more than 3\% of the total yield of cut-up chicken. Mahan (1996) suggested that excessive cellular damage resulting from oxidation may be the cause of drip loss. Surai (2002) reported that GSH-Px contributes significantly to the overall antioxidant defense of muscle in broilers; moreover, organic selenium supplementation of the diet could decrease tissue susceptibility to lipid peroxidation and increase the oxidative stability of skeletal muscles. Naylor et al. (2000) demonstrated that birds receiving dietary organic Se had significantly lower drip loss $(\mathrm{P}<0.01)$ than those receiving inorganic Se. These data are consistent with the findings of Downs et al. (2000) regarding broiler chickens ( $47 \%$ decrease in drip loss $24 \mathrm{~h}$ post-mortem). Also Naylor et al. (2000) and Upton et al. (2008) reported decreased drip loss (by 17 to 27\%) in SeY-fed compared with SeS-supplemented broilers. Downs et al. (2000) and Upton et al. (2008) found that breast meat drip loss increased when chickens were fed sodium selenite as compared with those fed selenized 
yeast and to no supplemental Se treatments. They concluded that sodium selenite supplementation may be associated with an oxidative process that promotes the post-mortem development of compromised cell membranes and facilitates increased moisture loss from processed breast meat.

\section{CONCLUSIONS}

Dietary supplementation with $0.3 \mathrm{mg} / \mathrm{kg}$ inorganic and organic selenium (Se) had no significant effect on growth performance, carcass, and muscle yields of turkeys.

Feed supplementation with sodium selenite did not affect glutathione peroxidase and superoxide dismutase activity, but the use of Se-enriched yeast significantly $(\mathrm{P}<0.05)$ increased the activity of those enzymes in the blood of turkeys.

Both Se sources had the same positive effect on the oxidative stability of meat during refrigerated storage, however, the Se-yeast were more effective in Seenrichment of breast muscles. A significant (more than twofold; $\mathrm{P}<0.05$ ) increase in selenium concentrations, an increase in crude fat content (of $31.5 \% ; \mathrm{P}<0.05$ ), a tendency towards a lower abdominal fat content (by 10.6\%), lower drip loss from raw meat (by 11.1-12.7\%) and lower cooking loss (by 5.5\%) were observed in the meat from turkeys fed diets supplemented with $0.3 \mathrm{mg} / \mathrm{kg} \mathrm{SeY}$ instead of sodium selenite.

\section{ACKNOWLEDGMENTS}

The authors gratefully acknowledge Alltech Poland, Bysławska 82, 04-968 Warsaw for supplying the Se-enriched yeast Sel-Plex ${ }^{\circledR}$.

\section{REFERENCES}

AOAC, 1990. Association of Official Analytical Chemists, Official Methods of Analysis. $15^{\text {th }}$ Edition. Arlington, VA

Cantor A.H., Moorehead P.D., Musser M.A., 1982. Comparative effects of sodium selenite and selenomethionine upon nutritional muscular dystrophy, selenium-dependent glutathione peroxidase, and tissue selenium concentrations of turkey poults. Poultry Sci. 61, 478-484

Collins V.C., Cantor A.H., Ford M.J., Straw M.L., 1993. Bioavailability of selenium in selenized yeast for broiler chickens. Poultry Sci. 72, 85-86

Combs Jr. G.F., 1981. Influences of dietary vitamin E and selenium on the oxidant defense system of the chick. Poultry Sci. 60, 2098-2105

Dlouhá G., Ševčiková S., Dokoupilová A., Zita L., Heindl J., Skřivan M., 2008. Effect of dietary selenium sources on growth performance, breast muscle selenium, glutathione peroxidase activity and oxidative stability in broilers. Czech J. Anim. Sci. 53, 265-269

Downs K.M., Hess J.B., Bilgili S.F., 2000. Fractionation and source effect on broiler carcass characteristics, meat quality, and drip loss. J. Appl. Anim. Res. 18, 61-72 
Draper H.H., Hadley M., 1990. Malondialdehyde determination as index of lipid peroxidation. Methods Enzymol. 86, 421-431

Fischer J., Bosse A., Most E., Mueller A., Pallauf J., 2008. Selenium requirement of growing male turkeys. Brit. Poultry Sci. 49, 583-591

Gutteridge J.M.C., 1984. Ferrous ion-EDTA stimulated phospholipide peroxidation. Biochem. J. 224, 697-701

Korniluk K., Czauderna M., Kowalczyk J., 2007. The influence of dietary conjugated linoleic acid isomers and selenized yeast on the fatty acid profile of the spleen, pancreas and kidneys of rats. J. Anim. Feed Sci. 16, 121-139

Mahan D.C., 1996. How organic selenium may help reduce drip loss. Misset World Poultry 12, 19-21

Mahan D.C., Parrett N.A., 1996. Evaluating the efficiency of selenium-enriched yeast and sodium selenite on tissue selenium retention and serum glutathione peroxidase activity in grower and finisher swine. J. Anim. Sci. 74, 2967-2974

Naylor A.J., Choct M., Jacques K.A., 2000. Effects of selenium source and level on performance and meat quality in male broilers. Poultry Sci. 79, 117-124

Niedźwiedzka K.M., Kowalczyk J., Czauderna M., 2008. Influence of selenate and linseed oil on fatty-acid and amino-acid profiles in the liver, muscles, fat tissues and blood plasma of sheep. J. Anim. Feed Sci. 17, 328-343

Northcutt J.K., Foegeding E.A., Edens F.W., 1994. Water-holding capacity of thermally preconditioned chicken breast and leg meat. Poultry Sci. 73, 308-316

NRC, 1994. Nutrient Requirements of Poultry. 9th revised Edition. National Academy Press. Washington, DC

Paglia D.E., Valentine W.N., 1967. Studies on the quantitative and qualitative characterization of erythrocyte glutathione peroxidase. J. Lab. Clin. Med. 70, 158-161

Payne R.L., Southern L.L., 2005. Comparison of inorganic and organic selenium sources for broilers. Poultry Sci. 84, 898-902

Popov I., Lewin G., 1999. Antioxidative homeostasis: characterization by means of chemiluminescent technique. Methods Enzymol. 300, 437-456

Rayman M.P., 2004. Review article. The use of high-selenium yeast to raise selenium status: how does it measure up?. Brit. J. Nutr. 92, 557-573

Ryu Y.C., Rhee M.S., Lee K.M., Kim B.C., 2005. Effects of different levels of dietary supplemental selenium on performance, lipid oxidation, and color stability of broiler chicks. Poultry Sci. 84, 809-815

Surai P.F., 2002. Selenium in poultry nutrition: a new look at an old element. 2. Reproduction, egg and meat quality and practical applications. World Poultry Sci. J. 58, 431-450

Tapiero H., Townsend D.M., Tew K.D., 2003. The antioxidant role of selenium and selenocompounds. Biomed. Pharmacotherapy 57, 134-144

Upton J.R., Edens F.W., Ferket P.R., 2008. Selenium yeast effect on broiler performance. Int. J. Poultry Sci. 7, 798-805

Wang Y.-B., Xu B.-H., 2008. Effect of different selenium source (sodium selenite and selenium yeast) on broiler chickens. Anim. Feed Sci. Tech. 144, 306-314

Woolliams J.A., Wiener G., Anderson P.H., McMurray C.H., 1983. Variation in the activities of glutathione peroxidase and superoxide dismutase in the concentration of copper in the blood in various breed crosses of sheep. Res. Vet. Sci. 34, 253-256

Yaroshenko F.O., Surai P.F., Yaroshenko Y.F., Karadas F., Sparks N.H.C., 2004. Theoretical background and commercial application of production of Se-enriched chicken. In: Proceedings of XXII World's Poultry Congress. Istanbul (Turkey) 